\title{
EFFECTS OF USE OF PROTECTED FATTY ACIDS IN EARLY LACTATING COWS FEEDING ${ }^{1}$
}

\author{
G. Grubić, M. Radivojević, N. Đorđević, M. Adamović, B. Spiridonović, B. Radomir ${ }^{2}$
}

Abstract: The influence of protected fatty acids in cow diets, during the first lactation phase, on the amount and chemical composition of milk and important physiological parameters was investigated. The experiment lasted 60 days on two groups of Holstein cows similar in age, lactation phase and milk production. Both groups (experimental and control) received diet with lucerne hay, lucerne haylage, maize plant silage, extruded soybeans and concentrate mixture with $18 \%$ crude protein. Cows in experimental group also received $0.5 \mathrm{~kg}$ of the product based on protected fatty acids.

The milk yield on $15,30,45$ and 60 -th day was not significantly different in the two groups. There were no significant differences $(\mathrm{P}>0.05)$ in $4 \% \mathrm{FCM}(31.0: 33.2 \mathrm{~kg})$. Milk fat percentage $(3.55: 3.56)$ and protein percentage $(2.93: 2.92)$. Urine tests were done three times (in days $1-7,27-33$ and $55-60$ of lactation). During the second urine test the significantly lower bilirubin concentration was determined in experimental group $(\mathrm{P}<0.01)$, while in the second and third test the significantly higher glucose content $(\mathrm{P}<0.01)$ was determined in experimental group $(2.5: 2.8 \mathrm{mmol} / \mathrm{L})$.

The experimental results showed that the use of protected fatty acids had no influence on the amount and composition of milk. The significant influence was observed only in some physiological parameters in cows.

Key words: cow, milk, physiological parameters, protected fatty acids.

\section{Introduction and literature review}

Ruminants are adapted to use carbohydrates as the main energy source, while the fat content in total energy supply is relatively small (Grubic et al., 2002). Diets for dairy cows have typically $1-4 \%$ of fat and only $50 \%$ of that are true fats, while the rest are fatty substances like carotenes, liposoluble vitamins and similar (Đorđević et al., 2003). Small amount of fat (oil) exists in cereal grains, especially in germs. On the other hand, there is much more fats (18-50\%) in some grains (soybeans, sunflower), but they are rarely used unprotected in ruminant nutrition (Nešić et al., 2001).

Fats from the diet are changed with enzymes produced by rumen microorganisms and the composition of lipids adsorbed by animals is significantly different from those supplied by the diet. There is significant amount of microbial lipid metabolism and de novo synthesis in the rumen. The use of fatty acids in rumen microorganisms is usually limited to incorporation in cells and for synthetic porpoises (Grubic and Adamović, 2003). Dietary lipids are hydrolyzed first in the rumen to free fatty acids and glycerol and after that fatty acids are biohydrogenated. The result is that ruminants mostly adsorb saturated fatty acids, which has influence on lipid consistence in their tissues and milk fat (Grubić et al., 2005).

The problem in energy supply in cow diets especially exists in high yielding animals that produce more than $35 \mathrm{~kg}$ milk per day, in the early post-partal period (Grubić and Adamović, 2003; Adamović et al., 1997). The reason is low intake during the first weeks of lactation, which as a result have insufficient intake of energy and nutrients. One of the ways to solve the problem of negative energy balance is to use quality feeds with high energy content. One of the ways to achieve that is to use protected fats or fatty acids (as calcium salt powder of pellets), which escape changes in the rumen and reach small intestines unchanged, where they are digested by lipase to fatty acids and glycerol and are adsorbed in that form. Population with lower milk production ( $<7000 \mathrm{~kg}$ milk per cow/year) normally do not need supplements in the form of additional fat.

The presence of some (unsaturated) fatty acids may have detrimental influence on microorganism population (Grubic et al., 1996; Bell et al., 2003). This is why it is advised to use protected fats which do not

2 Dr Goran Grubić, professor, dr Nenad Đorđević, assistant professor, Faculty of Agriculture, Nemanjina 6, 11081 Zemun; dr Milan Adamović, scientific advisor, Institute ITNMS, Franša D’Eperea 86, 11000 Belgrade; Mihailo Radivojević, dipl. inž., Institute PKB Agroekonomik; Bojan Spiridonović, dipl. inž., mr Borislav Radomir, Agricultural Corporation Belgrade, Industrijsko naselje bb, 11021, Padinska Skela; Serbia and Montenegro. 
have influence on microorganisms. In most cases additional fat has positive effects in high yield dairy cows (Castañeda-Gutiérrez et al., 2005; Veth et al. 2005; Solorzano and Kertz, 2005). The use of some feeds as additional fat source may have influence on conjugated linoleic acid content in milk fat. This fatty acid is important anticarcinogenic agent (Parodi, 1997), and may have positive effect on human health (Grubic et al., 2005). The content of some fatty acids in the diet, among other factors (concentrate/forage ratio, protein, fiber, feed conservation and others) has important influence on milk yield and amount and composition of milk fat (Gerson et al., 1983; Jovanović et al., 1997; Grubić et al., 2003).

\section{Material and methods}

The experiment lasted 60 days on two groups of Holstein cows, similar in age, lactation phase and milk production in this and previous lactations. There were $44 \%$ cows in third, $32 \%$ in fourth and $8 \%$ in fifth lactation. As the source of protected fatty acids a product called "Vegegold" was used. In both groups cows received diet with lucerne hay, lucerne haylage, maize plant silage, extruded soybeans and concentrate mixture with $18 \%$ crude protein. Cows in experimental group also received $0.5 \mathrm{~kg}$ of the product based on protected fatty acids („Vegegold“). The investigation of parameters of metabolic profile in urine (bilirubin, proteins, nitrates, glucose, ketone bodies) was done by „Medi test“", a fast urine-test, and also urine $\mathrm{pH}$ and viscosity were investigated three times during the investigation (in days 1-7, 27-33 and 55-60 of lactation). Blood samples were taken from jugular vein, 3-4 hours after morning feeding for glucose test on 1, 30 and 60 days of lactation. Milk yield was measured by metatrone on days 15, 30, 45 and 60 . On the last day of experiment the samples of milk were taken for analysis of protein and milk fat, which was done by „Milcoscan“. All results were statistically analyzed by T-test (Statistica v.6).

\section{Results and discussion}

The amount of produced milk had expected increasing trend during the experiment. In experimental group on 60th day there was slightly higher amount of $4 \%$ FCM and milk fat and lower in protein, but differences were not significant $(\mathrm{P}>0.05)$.

In some experiments the adding of the conjugated linoleic acid to the diet produced decrease in milk fat content within 24 hours (Baumgard et al., 2002). When the addition was stopped the milk fat percent reached earlier level. The mechanism of this influence is not completely clear but it is thought that such effect is produced by trans-10, cis-12 conjugated linoleic acid isomer (Bauman et al., 2001).

Results similar to ours were obtained by Adamovic et al. (1997) in an experiment where experimental group received fat concentrate (powdered protected fatty acid calcium salts) as $10 \%$ dry matter. The amount of produced milk in the experimental group was $11.05 \%$ higher, while protein and fat values in control and experimental treatments were $3.38: 3.39 \%$ and $2.92: 2.87 \%$ respectively. Robb et al. (1987) also determined that adding $0.5 \mathrm{~kg}$ "Megalac" increased 4\% FCM ( $29.49: 32.55 \mathrm{~kg})$ and milk fat (3.04: 3.18 $\%)$ production. Kraszewski et al (1993) determined that addition of $0.5 \mathrm{~kg}$ fat concentrate per cow/day resulted in better results during the summer compared with winter months. The significance on these results is in the fact that cow appetite is decreased in summer due to heat stress, which results in negative energy balance.

Table 1. Milk yield and composition

\begin{tabular}{|l|c|c|c|}
\hline \multirow{2}{*}{ Days of experiment and parameters } & \multicolumn{2}{|c|}{ Treatment } & \multirow{2}{*}{ Significance } \\
\cline { 2 - 3 } & Control & Experimental & \\
\hline Amount of milk, kg: & & & \\
\hline 15 day & 26.7 & 26.0 & NS \\
\hline 30 day & 28.6 & 28.4 & NS \\
\hline 45 day & 29.9 & 30.4 & NS \\
\hline 60 day & 30.7 & 31.7 & NS \\
\hline Amount of 4\% FCM, kg, 60 day : & 31.0 & 33.2 & NS \\
\hline Milk composition, 60 dan : & & & NS \\
\hline Milk fat- \% & 3.55 & 3.56 & NS \\
\hline Protein, \% & 2.93 & 2.92 & \\
\hline
\end{tabular}


The content of urobilinogen varied widely during the experiment, with the trend to decrease in the later phase (Table 2). Also the gradual decrease in bilirubin was observed. The difference between control and experimental group $(20.76$ : $6.76 \mu \mathrm{mol} / \mathrm{L})$ was significant $(\mathrm{P}<0.01)$. Protein and ketones in urine also had decreasing trend. In the first control period there was significant difference $(\mathrm{P}<0.01)$ in urine $\mathrm{pH}$ values. Specific weight of urine was parameter which remained constant.

Table 2. Results of urine analysis

\begin{tabular}{|l|c|c|c|c|c|c|}
\hline \multirow{2}{*}{ Parameters } & \multicolumn{5}{|c|}{ Treatment } \\
\cline { 2 - 8 } & \multicolumn{3}{|c|}{ Control } & \multicolumn{3}{c|}{ Experimental } \\
\hline Test number & 1 & 2 & 3 & 1 & 2 & 3 \\
\hline Urobilinogen, $\mu \mathrm{mol} / \mathrm{L}$ & 12.20 & 5.16 & 2.36 & 2.36 & 1.00 & 1.00 \\
\hline Bilirubin, $\mu \mathrm{mol} / \mathrm{L}$ & 34.44 & $20.76 \mathrm{a}$ & 15.40 & 28.48 & $6.76 \mathrm{~b}$ & 16.76 \\
\hline Protein, $\mathrm{mg} / \mathrm{dL}$ & 27.40 & 21.80 & 13.40 & 25.00 & 13.00 & 11.40 \\
\hline Ketones, $\mathrm{mmol} / \mathrm{L}$ & 2.10 & 0.60 & 0.10 & 0.60 & 0.20 & 0.20 \\
\hline $\mathrm{pH}$ & $7.4 \mathrm{a}$ & 6.8 & 7.0 & $7.1 \mathrm{~b}$ & 6.9 & 6.8 \\
\hline Specific weight, $\mathrm{g} / \mathrm{cm}^{3}$ & 1.001 & 1.000 & 1.000 & 1.000 & 1.000 & 1.000 \\
\hline
\end{tabular}

$a, b=$ values with different letters are significantly different $(P<0,01)$

The amount of glucose in blood varied very little $(2.4-2.8 \mathrm{mmol} / \mathrm{L})$. At the beginning the glucose content was very low, and it was slightly increased during lactation and remained within physiologically normal values in control group. In experimental group the increase in glucose content was significant, which may be result of the protected fat added (Table 3).

Tabela 3. Blood glucose content, $\mathrm{mmol} / \mathrm{L}$

\begin{tabular}{|l|c|c|c|}
\hline \multirow{2}{*}{ Sampling time } & \multicolumn{2}{|c|}{ Treatment } & Significance \\
\cline { 2 - 3 } & Control & Experimental & \\
\hline Day- 1. & 2.4 & 2.5 & NS \\
\hline Day 30. & 2.5 & 2.8 & $* *$ \\
\hline Day 60. & 2.5 & 2.8 & $* *$ \\
\hline \multicolumn{3}{|c|}{$* * P<0,01$}
\end{tabular}

Conclusion

In the experiment explained in this work, the use of "Vegegold", product based on protected fatty acids in the diets of dairy cows in the first phase of lactation had no significant influence on milk production and on milk fat and protein content. However, this product had positive effects on some physiological parameters, particularly those which indicate better energy supply (blood glucose). This justifies the use of such products in high yielding dairy cow feeding, since they have increased needs for energy in their diets.

\section{EFIKASNOST KORIŠĆENJA PROTEKTIRANIH MASNIH KISELINA U ISHRANI KRAVA U RANOJ LAKTACIJI}

G. Grubić, M. Radivojević, N. Đorđević, M. Adamović, B. Spiridonović, B. Radomir

\section{Rezime}

U radu je ispitivan uticaj protektiranih masnih kiselina u obrocima za krave, u prvoj fazi laktacije, na količinu i hemijski sastav mleka i važnije fiziološke parametre.

Eksperiment je izveden u trajanju od 60 dana, na dve grupe krave po 25 krava crno bele rase ujednačenih prema starosti, fazi laktacije i količini mleka u prethodnim laktacijama.

Obe grupe krava (kontrolna i ogledna) su dobijale obrok na bazi lucerkinog sena, lucerkine senaže, kukuruzne silaže, sirovog pivskog trebera, sojinog griza i smeše koncentrata sa $18 \%$ proteina. Pored 
navedenih hraniva, krave ogledne grupe dobijale su su i $0,5 \mathrm{~kg}$ proizvoda na bazi protektiranih masnih kiselina.

Količina mleka namužena $15 ., 30 ., 45$. i 60 . dana po telenju nije se statistički razlikovala između kontrolne i ogledne grupe. Nije bilo značajnosti razlika $(\mathrm{P}>0,05)$ u količini $4 \%$ mast korigovanog mleka $(31,0$ : $33,2 \mathrm{~kg})$, procenta mlečne masti u mleku $(3,55: 3,56)$ i procenta proteina u mleku $(2,93: 2,92)$. Testovi urina su obavljeni u tri navrata tokom ogleda ( između 1. i 7. dana; 27. i 33. dana i 55. i 60. dana nakon telenja). U drugom urino testu ustanovljena je značajno niža koncentracija bilirubina $u$ urinu ogledne grupe $(\mathrm{P}<0,01)$. Tridesetog i šezdesetog dana ogleda količina glukoze u krvi bila je značajno veća $(\mathrm{P}<0,01)$ kod ogledne grupe i prema redosledu grupa $(\mathrm{K}: \mathrm{O})$, u oba navrata, iznosila 2,5:2,8 $\mathrm{mmol} / \mathrm{l}$.

Rezultati ogleda ukazuju da korišćenje protektiranih masnih kiselina nije imalo značajnijeg uticaja na količinu i sastav mleka. Signifikantan uticaj ispoljen je na popravljanje nekih fizioloških parametara krava.

\section{References}

1. ADAMOVIĆ, M., STOIĆEVIĆ, LJ., JOVANOVIĆ, R., ŽEŽELJ, M., CVETKOVIĆ, D. (1997): Proizvodnja i korišćenje protektiranih masnih kiselina u prahu u ishrani visokomlečnih krava. VII Simpozijum: Tehnologija stočne hrane (sa međunarodnim učešćem). Tara. Zbornik radova, 76-83.

2. BAUMAN, D. E., PETERSON, D. G., CORL, B. A., BAUMGARD, L. H., PERFIELD II, J. W. (2001): Update on conjugated linoleic acids (CLA). Proc. Cornell Nutr. Conf. Pp. 170-178. Ithaca, New York.

3. BELL J. A. AND KENNELLY J. J. (2003) : Postruminal Infusion of Conjugated Linoleic Acids Negatively Impacts Milk Synthesis in Holstein Cows J. Dairy Sci. 86:1321-1324.

4. BAUMGARD, L. H., MOORE, C. E., BAUMAN, D. E. (2002): Potential application of conjugated linoleic acids in nutrient partitioning. Proc. Southwest Nutr. Conf. 127-141, Tucson, Arizona.

5. CASTAÑEDA-GUTIÉRREZ E., OVERTON T. R., BUTLER W. R., BAUMAN D. E. (2005): Dietary Supplements of Two Doses of Calcium Salts of Conjugated Linoleic Acid During the Transition Period and Early Lactation. J. Dairy Sci. 88:1078-1089.

6. ĐORĐEVIĆ, N., GRUBIĆ, G., JOKIĆ, Ž. (2003): Osnovi ishrane domaćih životinja-praktikum. Str. 52. Grafopapir-Šabac.

7. GERSON, T., JOHN, A.,SINCLAIR, B. R. (1983): The effect of dietary N on in vitro lipolysis and fatty acid hydrogenation in rumen digesta from sheep fed diets high in starch. J. Agric. Sci. (Camb.). 101: 97101.

8. GRUBIĆ, G., ALEKSIĆ, D., PAVLIČEVIĆ, A. (1996): Odnos kabaste i koncentrovane hrane u ishrani krava visoke mlečnosti. Poljoprivredne aktuelnosti, 3-4: 68-75.

9. GRUBIĆ, G., ADAMOVIĆ, M., STOJANOVIĆ, B., ĐORĐEVIĆ, N. (2002): Novi normativi u ishrani muznih krava. Mlekarstvo, 2: 37-42.

10. GRUBIĆ, G., ADAMOVIĆ, M. (2003): Ishrana visokoproizvodnih krava (monografija). Str. 168-171. Beograd.

11. GRUBIĆ, G., ADAMOVIĆ, M., STOJANOVIĆ, B., ĐORĐEVIĆ, N. (2003): Savremeni aspekti u normiranju potreba u proteinima za muzne krave. 3. Simpozijum: Ishrana, reprodukcija i zaštita zdravlja goveda. Vrbas. 23-27.09. Veterinarski glasnik, 57, 3-4: 101-112.

12. GRUBIĆ, G., ĐORĐEVIĆ, N., GLAMOČIĆ, D., STOJANOVIĆ, B., ADAMOVIĆ, O. (2005): Uticaj ishrane krava na sintezu nekih sastojaka mlečne masti. Simpozijum »Mleko i proizvodi od mleka«. Tara, 06.-10.04. 2005. Biotehnologija u stočarstvu, 21, poseban broj, 29-41.

13. JOVANOVIĆ, R., JORDANOSKI, N., KOLJAJIĆ, V., PAVLIČEVIĆ, A., DRINIĆ, M., GLAMOČIĆ, D. (1997): Current concept of feeding the high yielding dairy cows with the priteins nd carbohydrates. Symposium 50 years Faculty of Agriculture-Skopje. Jubilee Yearbook of the Faculty of Agriculture, Skopje, vol. 42., 195-202.

14. KRASZEWSKI J., WAWRZYNCZAK S., BIELAK, F. (1989): Przydatnase dodatku preparatu tluszezowego »Erafet« w postaci mydel wapniowych:magnezowych in zywieniu krow wysokomlecznych. Roczniki naukowe zootehniki, Krakow, 32-40.

15. NEŠIĆ, S., GRUBIĆ, G., STOIĆEVIĆ, LJ., ADAMOVIĆ, M., NIKOLIĆ, P., RADOMIR, B. (2001): Efekti korišćenja sirove soje u obrocima krava u prvih 100 dana laktacije. XV Savetovanje agronoma, veterinara i tehnologa. INI PKB Agroekonomik. Padinska Skela-Beograd. Zbornik naučnih radova, vol, 7, 1: 277-282. 
16. PARODI, P. W. (1997): Cows milk fat components as potential anticarcinogenic agents. Journal of Nutrition. 127: 1055-1060.

17. ROBB, E.(1987) : Response of early lactation dairy cows a low fat ration suplemented with »Megalac«. J. Dairy Sci. Vol.70., Supl.1.,

18. SOLORZANO L.C., KERTZ A. F. (2005): Rumen inert fat supplements reviewed for dairy cows. Feedstuffs. 77, 11:2-5.

19. VETH, S. K. GULATI, N. D. LUCHINI AND D. E. BAUMAN (2005): Comparison of Calcium Salts and Formaldehyde-Protected Conjugated Linoleic Acid in Inducing Milk Fat Depression. J. Dairy Sci. 88:1685-1693

20. STATSOFT, INC. (2003). STATISTICA (data analysis software system), version 6. www.statsoft.com. 